Article

\title{
Immunomodulatory and Antiviral Effects of Macroalgae Sulphated Polysaccharides: Case Studies Extend Knowledge on Their Importance in Enhancing Shellfish Health, and the Control of a Global Viral Pathogen Ostreid Herpesvirus-1 microVar
}

\author{
Sharon A. Lynch ${ }^{1, *(\mathbb{D})}$, Rachel Breslin ${ }^{1}(\mathbb{D})$, Babette Bookelaar ${ }^{1}$, Tawut Rudtanatip ${ }^{2} \mathbb{D}$, Kanokpan Wongprasert ${ }^{3}$ \\ and Sarah C. Culloty ${ }^{1,4}$
}

1 School of Biological, Earth and Environmental Sciences, Aquaculture Fisheries Development Centre and Environmental Research Institute, University College Cork, Cork T23 XE10, Ireland; 114757835@umail.ucc.ie (R.B.); babette_bookelaar@hotmail.com (B.B.); s.culloty@ucc.ie (S.C.C.)

2 Department of Anatomy, Faculty of Medicine, Khon Kaen University, Khon Kaen 40002, Thailand; tawut@kku.ac.th

3 Department of Anatomy, Faculty of Science, Mahidol University, Bangkok 10400, Thailand; kanokpan.won@mahidol.edu

check for updates

Citation: Lynch, S.A.; Breslin, R.; Bookelaar, B.; Rudtanatip, T.; Wongprasert, K.; Culloty, S.C. Immunomodulatory and Antiviral Effects of Macroalgae Sulphated Polysaccharides: Case Studies Extend Knowledge on Their Importance in Enhancing Shellfish Health, and the Control of a Global Viral Pathogen Ostreid Herpesvirus-1 microVar. Polysaccharides 2021, 2, 202-217. https://doi.org/10.3390/ polysaccharides 2020014

Academic Editor: Cédric Delattre

Received: 19 February 2021

Accepted: 23 March 2021

Published: 1 April 2021

Publisher's Note: MDPI stays neutral with regard to jurisdictional claims in published maps and institutional affiliations.

Copyright: (c) 2021 by the authors. Licensee MDPI, Basel, Switzerland. This article is an open access article distributed under the terms and conditions of the Creative Commons Attribution (CC BY) license (https:// creativecommons.org/licenses/by/ $4.0 /)$.
4 Marine and Renewable Energy Research Centre, University College Cork, Cork P43 C573, Ireland

* Correspondence: s.lynch@ucc.ie; Tel.: +353-(21)-4904615

\begin{abstract}
Macroalgae are the primary source of non-animal sulphated polysaccharides (SPs) in the marine environment with fucoidans derived from brown algae (Phaeophyta) and carrageenans from red algae (Rhodophyta). Much research has been carried out on SP effects on Asian shrimp species (genera Penaeus and Metapenaeus) but their effect on commercially important bivalve mollusc species is limited and in Pacific oyster Crassostrea gigas is unknown. Knowledge of their impact on bivalve pathogens and Palaemon shrimp is unknown. The objectives of this study were to assess the effects of Fucus vesiculosus (Phaeophyta), Mastocarpus stellatus (Rhodophyta) and algal derivatives (fucoidan and k-carrageenan) on C. gigas performance, and on ostreid herpesvirus-1 microvar (OsHV-1 $\mu$ Var) and bacteria Vibrio spp. development. Both pathogens have been associated with significant oyster mortalities and economic losses globally. The effects of sulphated galactan from Gracilaria fisheri (Rhodophyta) on European common prawn Palaemon serratus, an important fishery species, was also assessed. Findings indicate a rapid and prolonged increase in total blood cell count, lysozyme (enzyme that destroys pathogens), and a difference in the ratio of blood cell types in treated individuals compared to their control counterparts. A significantly lower OsHV-1 $\mu$ Var prevalence was observed in treated oysters and $\mathrm{k}$-carrageenan was found to suppress viral replication (loads), while OsHV-1 $\mu$ Var was not detected in the fucoidan treated oysters from Day 8 of the 26-day trial. No antibacterial effect was observed however, the oysters did not succumb to vibriosis. These findings contribute further knowledge to macroalgae sulphated polysaccharide biotherapeutic properties, their twofold effect on animal health and viral suppression.
\end{abstract}

Keywords: macroalgae sulphated polysaccharides; pacific oyster Crassostrea gigas; ostreid herpesvirus-1 microVar; European shrimp Palaemon serratus; antiviral

\section{Introduction}

Macroalgae (seaweed) are a prolific source of bioactive components in marine environments [1]. Such biocompounds boost vertebrate and invertebrate health by their immunostimulating, anticancer, antiviral and antibacterial activities [2,3]. A sulphated polysaccharide (SP) derived from brown algae (Phaeophyta) includes fucoidan $[4,5]$ while red seaweeds contain multiple SPs including sulphated galactans [6] and carrageenan [7] both of which are successful in the treatment of herpesvirus in humans [8,9]. In more recent 
studies, antiviral effects of SPs against a variety of enveloped viruses, such as Herpes Simplex Virus type 1 (HSV-1) and 2 (HSV-2), Human Immunodeficiency Virus (HIV), human cytomegalovirus, dengue viruses, respiratory syncytial and influenza viruses have been reported [10-12].

Alginic acid is generally the most abundant polysaccharide, with values reaching up to $59 \%$ DW in F. vesiculosus. Alginates (salts of alginic acid) are polyuronic saccharides consisting of $\beta$-D-mannuronic (M) and $\alpha$-L-glucuronic $(\mathrm{G})$ acid units linked together by $(1 \rightarrow 4)$ bonds, arranged heteropolymeric (MG) and/or homopolymeric (M or G) [13]. Fucoidans are particularly abundant in F. vesiculosus, which can accumulate up to $26 \%$ DW. Fucoidans are complex polysaccharides, ranging from 100 to $1600 \mathrm{kDa}$, being composed mainly of fucose and sulfate, although other monosaccharides (mannose, galactose, glucose, xylose, etc.), uronic acids or even acetyl groups and proteins may be present [13]. Laminarin is another polysaccharide of brown seaweeds and is a $\beta-1,3$-glucan, consisting of $\beta$-1,3-d-glucopyranose units interspersed with $\beta$-1,6-linked D-glucopyranose units forming branch-points or interchain residues [14]. Mastocarpus stellatus along with Irish moss Chondrus crispus were the first seaweed used for carrageenan extraction [15]. Carrageenans are a family of water soluble, linear, and sulfated galactans. They are composed of alternating 3-linked $\beta$-D-galactopyranose (G-units) and 4-linked $\alpha$-D-galactopyranose (D-units) or 4-linked 3,6-anhydro- $\alpha$-D-galactopyranose (DA-units), forming the disaccharide repeating unit of carrageenans [15]. The structure of fucoidans typically consist of a backbone of $(1 \rightarrow 3)$ - and $(1 \rightarrow 4)$-linked $\alpha$-L-fucopyranose residues, which can be separated in two types. Fucoidans from Fucus spp. have a type II arrangement and are essentially composed of fucose and sulfate, although small amounts of other monosaccharides may occur. Type II fucoidans consist of alternating $(1 \rightarrow 3)$ - and $(1 \rightarrow 4)$-linked $\alpha$-L-fucopyranose residues [16].

The Pacific oyster Crassostrea gigas is one of the most commercially important aquaculture species worldwide (http: / / www.fao.org/fishery/culturedspecies /Crassostrea gigas/en, accessed 26 March 2021). C. gigas are filter feeding bivalves that ingest plankton and organic particles from the water column [17]. C. gigas stocks have suffered significant summer mortalities globally due to a complex aetiology, primarily associated with diseasecausing pathogens such as ostreid herpesvirus-1 microVar (OsHV-1 $\mu$ Var) and variants, as well as Vibrio spp. bacteria, [18-21]. The common prawn Palaemon serratus is found in the Atlantic Ocean from Denmark to Mauritiana, and the Mediterranean and Black Seas, and is a commercially valuable trap fishery primarily in the UK and Ireland [22]. P. serratus are omnivorous and will feed on macroalgae [22].

Shellfish species rely on an innate immune system, which can be directly and/or indirectly affected by their environment $[23,24]$. Their effective innate immune responses and mechanisms involve immune cells, genes and proteins [25] and is responsible for providing resistance to microbial pathogens and preventing disease outbreaks [26-28]. Vaccination against infectious pathogens and diseases in these species is not possible [29]. Haemocytes (blood cells) are the primary defence mechanism in shellfish [30] and the cellular protein lysozyme is an enzyme linked with the destruction of pathogens or "nonself" and is also an indicator of physiological condition and vitality [31-33]. Two types of haemocytes, hyalinocytes/hyaline and granulocytes/granular, are involved in immunological defence $[30,34]$. Lysozymes support the immune system by lysing cell walls of invading particles, which lead to osmotic and mechanical stress in the cell and often death [35].

In recent years, it has been highlighted that seaweeds can be a beneficial diet source for bivalve molluscs [36]. Porphyra haitanensis (Rhodophyta) was found to be a successful substitute diet in the nursery production of Belcher's cupped oyster Crassostrea belcheri [37,38]. Extracted SPs from Chondrus crispus (Rhodophyta) induced health enhancing activities in the blue mussel Mytilus spp. at a cellular, humoral and molecular level [39]. Extracted SPs from red seaweed spp. have been successfully used in Asian aquaculture of giant tiger prawns Penaeus monodon and Whiteleg shrimp Litopenaeus vannamei in the fight against infection with white spot syndrome virus (WSSV) [40,41]. Significantly greater hyaline cells (HC), granular cells (GC), and total haemocyte count (THC) were reported in L. vannamei after they were fed a diet incorpo- 
rated with $\lambda$-carrageenan [42]. Carrageenan has been found to increase the immune-related expression in shrimp L. vannamei through oral administration $[43,44]$. Dietary administration of SPs from Asparagopsis taxiformis, Gracilaria tenuistipitata, and Gracilaria verrucosa resulted in significantly higher HC, GC, and THC in P. monodon and L. vannamei $[43,45,46]$. P. monodon treated with a diet of Asparagopsis spp. (Rhodophyta) were able to suppress and control infection with Vibrio spp. [47].

The objectives of this study were to assess the biotherapeutic and antimicrobial effects of red and brown seaweed spp. and their SP derivatives on C. gigas and two associated pathogen groups of significance, ostreid herpesvirus-1 microVar and Vibrio spp., and $P$. serratus for the first time in laboratory-based trials. The seaweed species chosen are commonly found at oyster culture and near shore coastal locations where both shellfish species occur $[48,49]$. Findings from these studies will not only fill the knowledge gaps that exist with regards the benefits of macroalgae spp. and their biocompounds on commercially important marine invertebrate species, but also on a significant global marine virus.

\section{Materials and Methods}

2.1. The Effects of (a) Intact Seaweed and (b) Extracted Derivatives on Pacific Oyster Crassostrea Gigas Performance and Pathogen Development

(a) This study investigated the effects of crude seaweed (Figure 1) and extracted seaweed derivatives on the innate immunity of $C$. gigas and associated pathogen development.

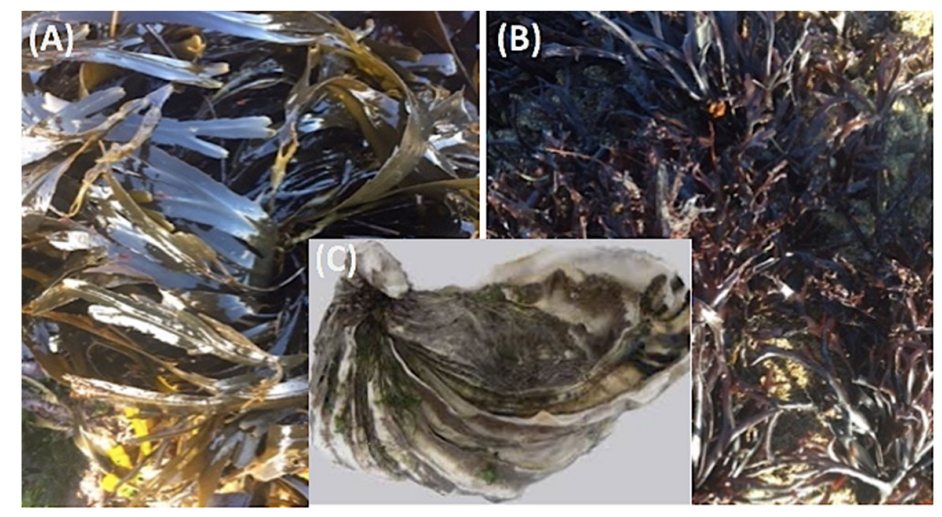

Figure 1. Seaweed species (A) Bladder wrack Fucus vesiculosus, (B) false Irish moss Mastocarpus stellatus, and (C) Pacific oyster Crassostrea gigas.

Oysters with a whole wet weight range of 0.35-7.36 g were sourced from an Irish oyster culture site where ostreid herpesvirus- 1 microVar (OsHV- $1 \mu$ Var) is endemic. Prior to the trial commencing, the seaweed was washed with tap water to remove all attached organisms including pathogens. A total of $100 \mathrm{~g}$ of each seaweed species (water squeezed out and blotted dry) that were attached to oyster culture bags was used per experimental tank (Figure 1). Although sulphate concentrate was not analysed, the amount of seaweed that the oysters were exposed to was based on seaweed density attached to the oyster trestle bags in the field. The mineral content, including sulphate concentrations varied between 2.4-11.5 g/100 g dry weight and $3.75 \mathrm{~g} \pm 0.04 / 100 \mathrm{~g}$ dry weight for F. vesiculosus [50] and $0.6-3.9 \mathrm{~g} / 100 \mathrm{~g}$ for M. stellatus [51].

Three replicates were used per treatment, i.e., (a) oysters held with F. vesiculosus, (b) oysters held with $M$. stellatus and (c) control oysters held with no seaweed. Thirty oysters consisting of seed and adults were used per tank, resulting in 90 control oysters and 90 oysters per treatment in total. The oysters and seaweed species were held in stand-alone aquaria $(10 \mathrm{~L})$ treated with $4 \mathrm{~mL}$ of a biofilter treatment Seachem Stability ${ }^{\circledR}$ that rapidly and safely establishes a bio-filter and prevents "New Tank Syndrome" at the start of each trial to ensure optimal water quality in all of the tanks for 26 days at a salinity of 34. During the first 19 days the oysters were exposed to $14{ }^{\circ} \mathrm{C}$, after Day 19 the temperature went up to $19^{\circ} \mathrm{C}$ for 7 days (up until Day 
26) to apply a thermal shock to the oysters and encourage viral replication in the system. The tanks were exposed to $12 \mathrm{~h}$ of darkness and $12 \mathrm{~h}$ of light. No water changes were conducted for the duration of the trial and oysters were fed $2 \mathrm{~mL}$ of Shellfish Diet 1800 (Reed Mariculture, A mixed diet of Isochrysis, Pavlova Thalassiosira, Tetraselmis, size: 5-12 microns, dry weight 8\%, more information: (https:/ / reedmariculture.com/product_shellfish_diet_1800.php, last accessed 26 March 2021) at Day 7, 14 and 21.

An initial/baseline sample of oysters $(n=30)$ was processed prior to the trial commencing for pathogen screening. The oysters were checked for mortality several times daily and any moribund or dead individuals were removed immediately and processed. On Days 2, 5, 7, 12, 19 and 22 three oysters per tank were randomly selected and processed, resulting in a total of 9 oysters per treatment and control at fixed time points during the trial. All remaining oysters dead or alive were processed on the final day of the trial (Day 26).

For the detection of OsHV-1 $\mu$ Var, DNA was extracted from oyster gill tissue (approximately $\left.5 \mathrm{~mm}^{2}\right)$ using the Chelex-100 method ( $10 \mathrm{~g}$ of Chelex in $100 \mathrm{~mL}$ of $\mathrm{ddH}_{2} \mathrm{O}$ ) [52]. The oyster gill tissue was added to $100 \mu \mathrm{L}$ of Chelex solution in a $0.5 \mathrm{~mL}$ Eppendorf safe lock tube. Samples were then placed in a Hybaid thermocycler and heated at a temperature of $99{ }^{\circ} \mathrm{C}$ for $1 \mathrm{~h} 15 \mathrm{~min}$ to facilitate cell lysis. A polymerase chain reaction (PCR) [18] and quantitative PCR (qPCR) [53] was carried out to determine presence/absence of OsHV-1 $\mu$ Var and determine the viral load in oysters, respectively. In the PCR [18], $2 \mu \mathrm{L}$ genomic DNA template per individual was screened. Expected size of amplified PCR products for OsHV-1 $\mu$ Var was $385 \mathrm{bp}$ and PCR was carried out in $25 \mu \mathrm{L}$ containing $12.9 \mu \mathrm{L} \mathrm{ddH}_{2} 0$, $5 \mu \mathrm{L}, 5 \times$ buffer, $5 \mu \mathrm{L}$ dNTPs $(0.2 \mathrm{mM}), 0.5 \mu \mathrm{L} \mathrm{MgCl}_{2}(25 \mathrm{mM}$ stock $), 0.25 \mu \mathrm{L}$ of each primer OHVA/OHVB (100 pmol mL-1 stock), and $0.1 \mu \mathrm{L}$ Taq DNA polymerase. Positive controls (triplicate) consisting of OsHV-1 $\mu$ Var infected oyster tissue and negative controls (triplicate) of double distilled water $\left(\mathrm{ddH}_{2} \mathrm{O}\right)$ were used for each PCR. Thermo cycling conditions were performed by initial denaturation of 1 min of $95^{\circ} \mathrm{C}$, following by 35 cycles including a denaturation step of $20 \mathrm{~s}$ at $94{ }^{\circ} \mathrm{C}$, an annealing step of $30 \mathrm{~s}$ at $56{ }^{\circ} \mathrm{C}$ and an elongation step at $72{ }^{\circ} \mathrm{C}$ and finishing with a final elongation step of $7 \mathrm{~min}$ at $72{ }^{\circ} \mathrm{C}$ by using a thermo Hybaid PCR express thermal cycler. Presence of amplified PCR products was confirmed by electrophoresis using a $2 \%$ agarose gel stained with ethidium bromide (10 mg/L stock) and was run with an electrical charge of $110 \mathrm{~V}$ for $60 \mathrm{~min}$.

In the qPCR [53], all qPCRs used a total of $5 \mu \mathrm{L}$ genomic DNA template per individual (duplicate). The qPCR mix was carried out in $25 \mu \mathrm{L}$ containing $12.5 \mu \mathrm{L} 2 \times$ Brilliant Sybr Green ${ }^{\circledR} \mathrm{Q}$ PCR Master Mix, $2.5 \mu \mathrm{L}$ HVDP-F $(5 \mu \mathrm{M})$ and $2.5 \mu \mathrm{L}$ HVDP-R $(\mu \mathrm{M})$ primers and $2.5 \mu \mathrm{L} \mathrm{ddH_{2 }}$ O. Standards were used to detect the exact number of viral copies in tested samples. Standard curves were prepared by diluting a viral DNA suspension of $10^{8}$ viral copies of OsHV-1 (supplied by IFREMER). qPCR plates included 5 dilutions of $10^{5}, 10^{4}, 10^{3}$, $10^{2}$ and $10^{1}$ viral copies. Thermo cycling conditions were performed by initial denaturation of $2 \mathrm{~min}$ of $50{ }^{\circ} \mathrm{C}$ and $10 \mathrm{~min}$ at $95^{\circ} \mathrm{C}$, following by 40 cycles of $15 \mathrm{~s}$ at $95^{\circ} \mathrm{C}$ and $1 \mathrm{~min}$ at $60{ }^{\circ} \mathrm{C}$ and a melt curve of $95^{\circ} \mathrm{C}$ for $15 \mathrm{~s}, 60^{\circ} \mathrm{C}$ for $1 \mathrm{~min}, 95^{\circ} \mathrm{C}$ for $30 \mathrm{~s}$ and $60^{\circ} \mathrm{C}$ for $15 \mathrm{~s}$ in a 7500-thermal cycler (Life Technologies).

To evaluate oyster immune function, haemolymph was collected and lysozyme levels and activity were measured [32] according to [54]. The haemolymph serum was defrosted and $30 \mu \mathrm{L}$ of serum was placed in triplicate into a 96 well round flat-bottomed plate. $170 \mu \mathrm{L}$ of the Micrococcus lysodeikticus suspension $\left(0.2 \mathrm{mg} \cdot \mathrm{mL}^{-1}\right.$ sodium phosphate buffer $\mathrm{pH} 6.4$, store at $-20^{\circ} \mathrm{C}$ ) was added to the serum and the decrease in absorbance was recorded at $450 \mathrm{~nm}$ every minute for the following 4 min using a Spectra III SLT plate reader.

(b) In the laboratory trial to assess the effects of commercial seaweed biocompounds fucoidan and kappa ( $\mathrm{k}$ )-carrageenan, oysters from the same age cohort (approximately 1 year old, $3.835 \mathrm{~g} \pm 1.19$ (SD) with a weight range of 2.01-8.69 g) were used from an oyster culture site where both pathogens are endemic. K-carrageenan and fucoidan (MERCKSigmaAldrich Ireland Ltd., Arklow, Co., Wicklow, Ireland) were used in the trial.

Prior to the trial starting, 30 oysters from the initial batch of 300, were processed and screened for the presence of OsHV-1 $\mu$ Var and Vibrio spp. The experiment consisted of 
nine stand-alone plastic aquaria (10 L volume). Three of the tanks acted as controls (no algal dose), whilst the two algal treatments had 3 tanks each, with each tank containing 20 C. gigas. The dose amount added was $300 \mu \mathrm{g}$ of algal extract/g of oyster per tank, i.e., for every $1 \mathrm{~g}$ (wet weight) of oyster $300 \mu \mathrm{g}$ of $\mathrm{k}$-carrageenan or fucoidan was added to each tank for example if the wet weight of oysters in a tank was $30 \mathrm{~g}$ than $9000 \mu \mathrm{g}$ of the algal extract was added to that tank, as this dose amount was observed to have an effect when native oysters $O$. edulis were administered a dose of zymosan [33]. The trial ran for a duration of 14 days, excluding the first 5 days prior to the trial to allow the animals to acclimate. The oysters were kept at ambient room temperature, with salinity being kept at $33 \mathrm{ppt}$ and tank water temperature ranging from 14.9 to $16.2^{\circ} \mathrm{C}$. A biofilter treatment consisting of $4 \mathrm{~mL}$ of Seachem Stability ${ }^{\circledR}$ was added to each of the tanks to ensure optimal water quality. The tanks were checked three times daily, and any dead individuals were removed and processed. Living specimens were sampled at $12 \mathrm{~h}, 24 \mathrm{~h}, 48 \mathrm{~h}$, and on days 5 , 8 , and 10, with the remaining oysters being collected and screened on Day 14 . Throughout the study, the tank water was not changed, and the oysters were not fed.

During the processing of the oysters, gill tissue (approximately $5 \mathrm{~mm}^{2}$ ) was taken for DNA extraction (chelex) to screen for OsHV-1 $\mu$ Var and V. aestuarianus. PCR and qPCR were carried out to screen for OsHV-1 $\mu$ Var [18,53], V. aestuarianus [55] and Vibrio spp. [56,57] validated by Sanger sequencing and qPCR). In the V. aestuarinaus qPCR [58], a total of $5 \mu \mathrm{L}$ of DNA per invertebrate was used to detect Vibrio aestuarianus prevalence. The

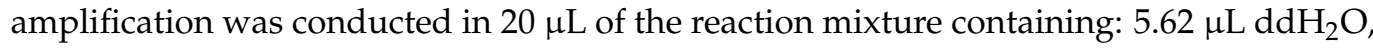
$0.75 \mu \mathrm{L}$ of $5 \mu \mathrm{M}$ forward primer (dnaJ f420), $0.75 \mu \mathrm{L}$ of $5 \mu \mathrm{M}$ reverse primer (dnaJ r456), $0.38 \mu \mathrm{L}$ of $5 \mu \mathrm{M}$ of probe $(d n a J \mathrm{p} 4413)$ and $12.5 \mu \mathrm{L}$ of $2 \mathrm{x}$ Taqman mastermix, using a 7500-thermal cycler (Life Technologies). qPCR was completed using a thermal profile of $50{ }^{\circ} \mathrm{C}$ for $2 \mathrm{~min}$ and $95^{\circ} \mathrm{C}$ for $10 \mathrm{~min}$, followed by 40 cycles of $95^{\circ} \mathrm{C}$ for $15 \mathrm{~s}$ and $60{ }^{\circ} \mathrm{C}$ for 30 s. All samples were performed in triplicate. Negative controls $(n=3)$ of $5 \mu \mathrm{L}$ double distilled water $\left(\mathrm{ddH}_{2} \mathrm{O}\right)$ were used; likewise, positives controls $(n=3)$ contained $5 \mu \mathrm{L}$ Vibrio infected DNA. $C_{T}$ values were used to determine real-time TaqMan PCR quantitation and detection limits, a tested sample is considered positive if its mean Ct value was below 37.

In the Vibrio spp. [56,57] PCR. The PCR reaction mix contained $2.5 \mu \mathrm{L}$ of DNA, $0.25 \mu \mathrm{L}$ each of forward and reverse primers (Vibf/Vibr, $100 \mathrm{pmol} / \mathrm{mL}$ ), $0.1 \mu \mathrm{L}$ of GoTaq, $0.5 \mu \mathrm{L}$ $\mathrm{MgCl}_{2}(25 \mathrm{mM}), 1.5 \mu \mathrm{L}$ of DMSO, $5 \mu \mathrm{L}$ of $5 \times$ Green buffer, $5 \mu \mathrm{L}$ of DNTPs $(0.2 \mathrm{mM})$, and $12.9 \mu \mathrm{L}$ of $\mathrm{ddH}_{2} \mathrm{O}$ per each individual oyster being screened. Negative controls used were $\mathrm{ddH}_{2} \mathrm{O}$ while positive controls of purified Vibrio aestuarianus DNA $(2.5 \mu \mathrm{L})$ (Marine Institute, Ireland) was used. The thermocycling conditions for the PCR consisted of $1 \mathrm{~min}$ at $95{ }^{\circ} \mathrm{C}$ denaturation phase, 35 cycles of $94{ }^{\circ} \mathrm{C}$ for $20 \mathrm{~s}, 56{ }^{\circ} \mathrm{C}$ for $30 \mathrm{~s}, 72{ }^{\circ} \mathrm{C}$ for $30 \mathrm{~s}$, for denaturation, annealing and elongation, respectively. This was followed by a final elongation phase of $7 \mathrm{~min}$ at $72{ }^{\circ} \mathrm{C}$. Visualisation of PCR products $(286 \mathrm{bp}$ ) by agarose gel electrophoresis using SYBR safe dye was recorded. For the latter diagnostic tool, the PCR primers were specific to Vibrio spp., as confirmed by Sanger sequencing.

Heart smears were carried out to conduct the total blood cell count (TBC) and differential blood cell count (DBC). Estimated Total blood cell count was found by examining heart smear slides under $40 \times$ magnification and obtaining the average number of blood cells for 10 high power fields ( $40 \times$ objective), and multiplying the average number found by 2000 to obtain an estimated total white blood cell count per microliter [58,59]. Differential blood cell (DBC) counts were carried out by using two hand-held clickers, and counting the number of hyalinocytes and granulocytes present, until 100 blood cells were counted in total $[60,61]$.

\subsection{Immunological Effects of Naturally Extracted Sulphated Polysaccharides from a Red Seaweed Gracilaria Fisheri on Shrimp (European Common Prawn) Palaemon Serratus}

Wild P. serratus with a weight range of 3.0-4.1 $\mathrm{g}$ and a length range of $7.0-7.8 \mathrm{~cm}$ were collected from pots at Lough Hyne Marine Nature Reserve, Co., Cork, Ireland $\left(51^{\circ} 30^{\prime} 7.43^{\prime \prime}\right.$ N-9 $\left.18^{\prime} 19.82^{\prime \prime} \mathrm{W}\right)$ (Figure 2). 


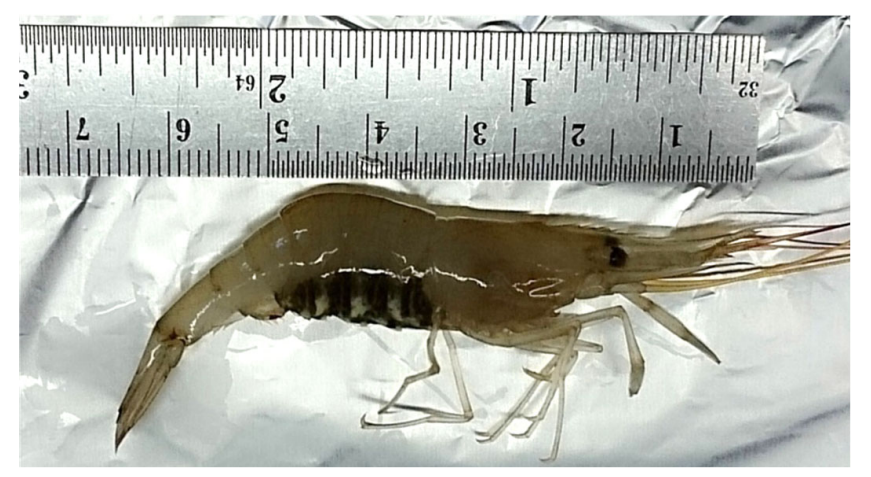

Figure 2. The European common prawn Palaemon serratus.

Sulphated galactans $(\mathrm{Sg})$ were extracted from the red seaweed G. fisheri collected from the Shrimp Genetic Improvement Center (SCIG), Chaiya district, Surat Thani Province, Thailand. The structure of Sgs consisted of the linear backbone of alternating 3-linked $\beta-D-$ galactopyranose and 4-linked 3,6-anhydro- $\alpha$-L-galactopyranose or $\alpha$-L-galactose 6 sulfate units [62].

The shrimp were held in stand-alone plastic aquaria $(10 \mathrm{~L})$, fed with pellet diets and acclimated for 7 days prior to the trial commencing at a salinity of 34 in a constant temperature room $\left(10^{\circ} \mathrm{C}\right)$. The tanks were exposed to $12 \mathrm{~h}$ of darkness and $12 \mathrm{~h}$ of light. A biofilter treatment consisting of $4 \mathrm{~mL}$ of Seachem Stability ${ }^{\circledR}$ was added to each of the tanks to ensure optimal water quality.

The treatments included (a) shrimp not exposed to sulphated galactans, (b) shrimp exposed to a low dose of Sg (final concentration of $5 \mu \mathrm{g}$ of $\mathrm{Sg} / \mathrm{mL}$ of tank seawater, i.e., $50 \mu \mathrm{g}$ of Sg per tank) and (c) shrimp exposed to a high dose of sulphated galactans (final concentration of $50 \mu \mathrm{g}$ of $\mathrm{Sg} / \mathrm{mL}$ of tank seawater, i.e., $500 \mu \mathrm{g}$ of $\mathrm{Sg}$ per tank). Each treatment was performed in duplicate. Sixteen shrimp were used per tank, giving 32 control shrimp and 32 shrimp per treatment in total. Sulphated galactans was added into the tank and no water changes were conducted for the duration of the trial (10 days) to ensure that the amount of sulphated galactans added to the water was not altered in the system. On Days 3, 4, 5, 7 and 10 of the trial, three shrimp were arbitrarily selected from each tank to determining the total haemocyte count (THC). An initial/baseline sample of shrimp $(n=5)$ was processed prior to the trial commencing.

To determine the THC, $100 \mu \mathrm{L}$ of haemolymph was withdrawn from the ventral sinus and mixed with $100 \mu \mathrm{L}$ of $10 \%$ formalin in $0.45 \mathrm{M} \mathrm{NaCl}$. After incubation for $10 \mathrm{~min}, 20 \mu \mathrm{L}$ of haemocyte mixture was stained with $20 \mu \mathrm{L}$ of Rose Bengal solution (1.2\% Rose Bengal in 50\% ethanol) and further incubated at room temperature for $20 \mathrm{~min}$ before being used to determine THC by a hemocytometer (improved Newbauer bright line) under a light microscope at $20 \times$ magnification [63].

\subsection{Statistics}

\subsubsection{Crassostrea gigas Exposed to Intact Seaweed}

Oyster mortality and prevalence of infection were analysed by Chi-square test. Differences in lysozyme amount and activity were tested by Student's $t$-test. For both tests, significant differences at $p \leq 0.05$ were considered.

\subsubsection{Crassostrea gigas Exposed to Extracted Derivatives}

The data were presented as mean \pm SD and analysed by Chi-square test, and statistically significant difference was required at $p$-value $\leq 0.05$. Statistical significance was calculated via one-way ANOVA analysis followed by a Tukey test were performed on data in Rstudio. Values of $p \leq 0.05$ were considered to be statistically significant. 


\subsubsection{Palaemon serratus Exposed to Extracted Sulphated Galactans}

All assays were performed in triplicate. The data were presented as mean $\pm \mathrm{SD}$ and analysed by one-way ANOVA followed by Tukey's multiple comparison. Statistically significant difference was required at $p \leq 0.05$.

\section{Results and Discussion}

3.1. Exposure of Crassostrea Gigas to Intact Seaweed Species Fucus Vesiculosus and Mastocarpus Stellatus

Results indicated that oysters exposed to either of the seaweed species showed significantly lower OsHV-1 $\mu$ Var prevalence and viral loads compared to control oysters throughout the 26-day trial (Figure 3). The initial oyster sample from the C. gigas culture site had a prevalence of $53.33 \%$ for OsHV- $1 \mu$ Var. An overall OsHV-1 $\mu$ Var prevalence of $22.0 \%$ was detected in oysters exposed to $F$. vesiculosus while it was $23.1 \%$ for oysters exposed to M. stellatus. Control oysters had a significantly higher overall prevalence of $39.8 \%$ compared with the oysters exposed to the seaweed species $\left(X^{2}=9.1, \mathrm{df}=2, p=0.01\right)$. Minimal mortalities were observed in all oyster groups.

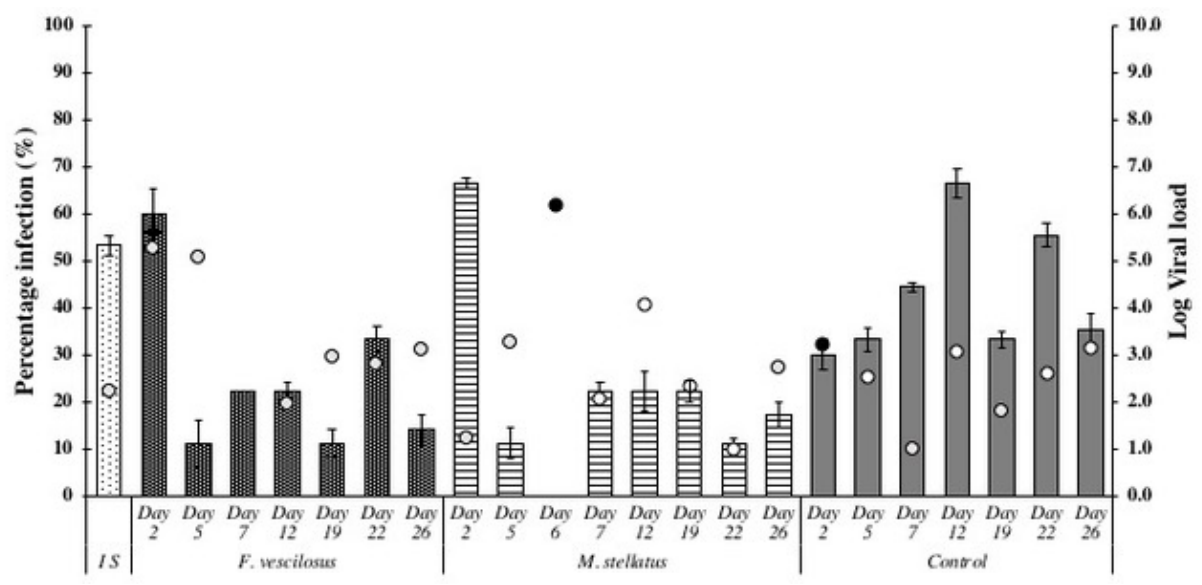

Figure 3. Prevalence of ostreid herpes virus-1 microVar (OsHV-1 $\mu$ Var) and viral load (white round marker: living oysters, black round marker: dead oysters) in oysters exposed to seaweed species and control oysters.

In the blood lysozyme amount analyses, the initial oyster sample showed an average OD absorbance of 0.221 for uninfected individuals and 0.199 for infected individuals in the baseline sample, indicating a lower blood lysozyme amount in uninfected oysters (Figure 4). During the first week of the trial the blood lysozyme amount was higher but not significantly so in uninfected oysters held with both seaweed species compared with the control oysters (Figure 4). A similar trend was observed in OsHV-1 $\mu$ Var infected oysters up until Day 5 of the trial for oysters held with M. stellatus and between Days 12 and 19 while the effects were more long term in oysters held with F. vesiculosus (<Day 22). No significant differences were observed between seaweed exposed and control uninfected oysters (Figure 4A). Significant difference for lysozyme amount between control and seaweed exposed oysters was observed in oysters exposed to the F. vesiculosus on Day $22(p<0.01)$ (Figure 4B). 


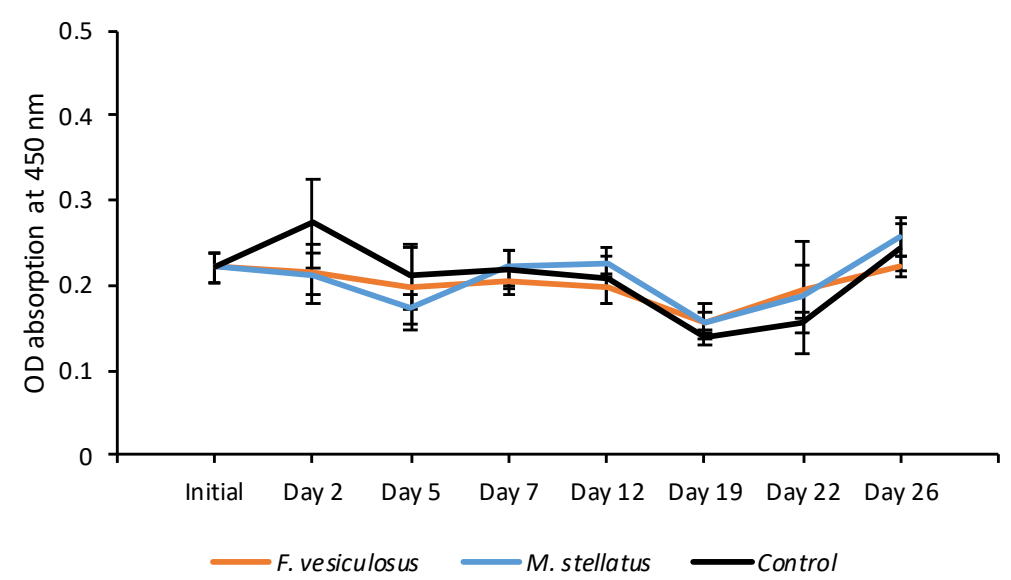

(A)

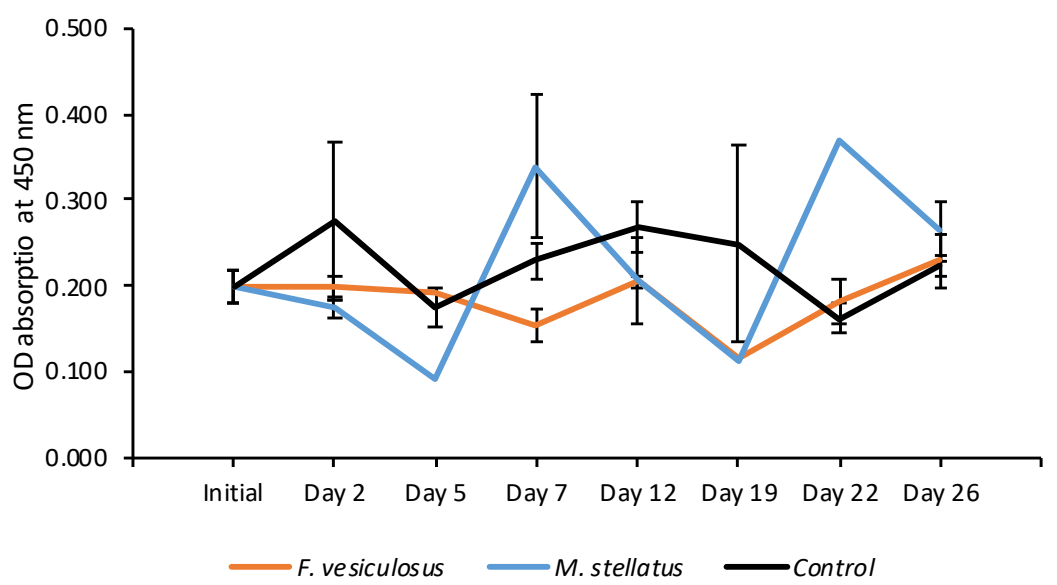

(B)

Figure 4. Lysozyme amount for (A) uninfected and (B) OsHV-1 $\mu$ Var infected oysters based on average (+SE) OD absorbance. A low value indicates a high blood lysozyme amount and a high value indicates a low blood lysozyme amount.

Over the 26 Day study period no significant differences in oyster performance, such as mortality and lysozyme activity, were observed between the treatments.

3.2. Effects of Fucoidan and Kappa ( $\kappa$ ) Carrageenan on Crassostrea Gigas and Pathogens (OsHV-1 $\mu$ Var and Vibrio spp (V. splendidus)

For the duration of trial period, no $C$. gigas mortalities were observed in the control and algal treated tanks, including individuals who were selected for processing at the allocated sample time periods. No mortalities occurred in the tanks by week 9 (post trial period) in all three oyster groups.

The initial oyster sample $(n=30)$ tested negative for OsHV- $1 \mu$ Var by PCR, and was negative for $V$. aestuarianus by qPCR, however in the generic Vibrio spp. PCR, $26.7 \%$ of the oysters amplified a product (subsequently confirmed to be Vibrio splendidus by Sanger sequencing). Overall, for the duration of the two-week trial the control oysters had the highest prevalence of herpesvirus $(43.05 \%)$ while oysters treated with each of the algal extracts (carrageenan and fucoidan) had a significantly lower herpesvirus prevalence ( $30.4 \%$ and $26.1 \%$, respectively) (Figure 5). In the fucoidan treatment group, there was no detection of the virus in oysters from Day 8 up until the end of the trial, while the virus persisted in the control group. 


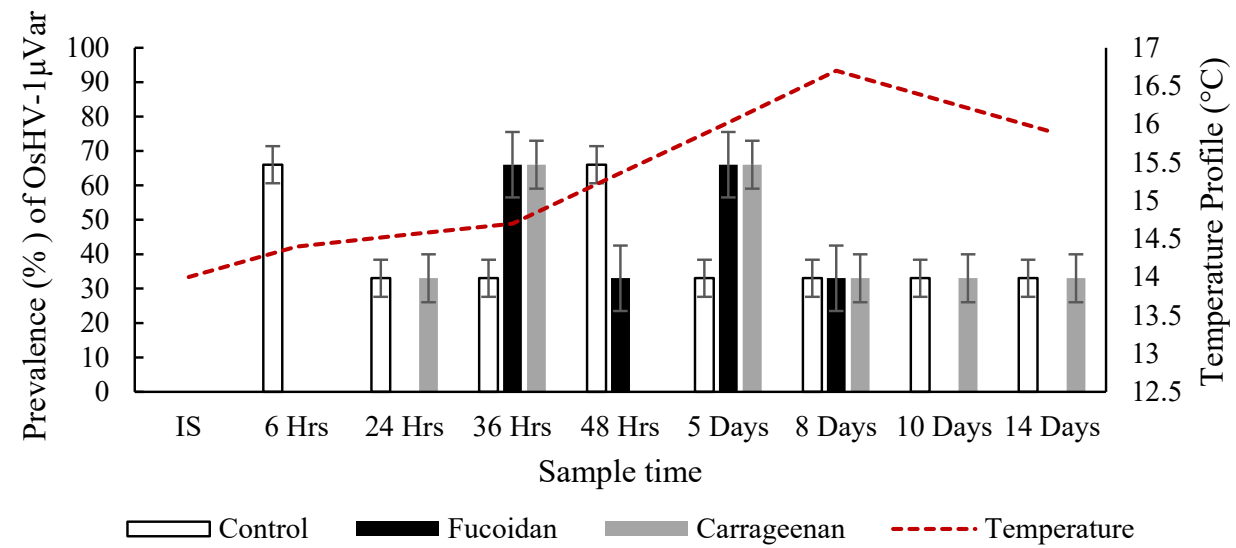

Figure 5. Prevalence (\%) of OsHV-1 $\mu$ Var in oysters from the control and algal treated systems including ambient temperature.

In the qPCR, OsHV-1 $\mu$ Var was replicating with increased viral loads (lower CT values) in the control oysters (up until Day 14) and in the fucoidan treated oysters (up until last detection on Day 8) and although it was present for the duration of the trial in the carrageenan treated oysters it was not replicating, as the viral loads remained the same from the start to the end of the trial (Figure 6).

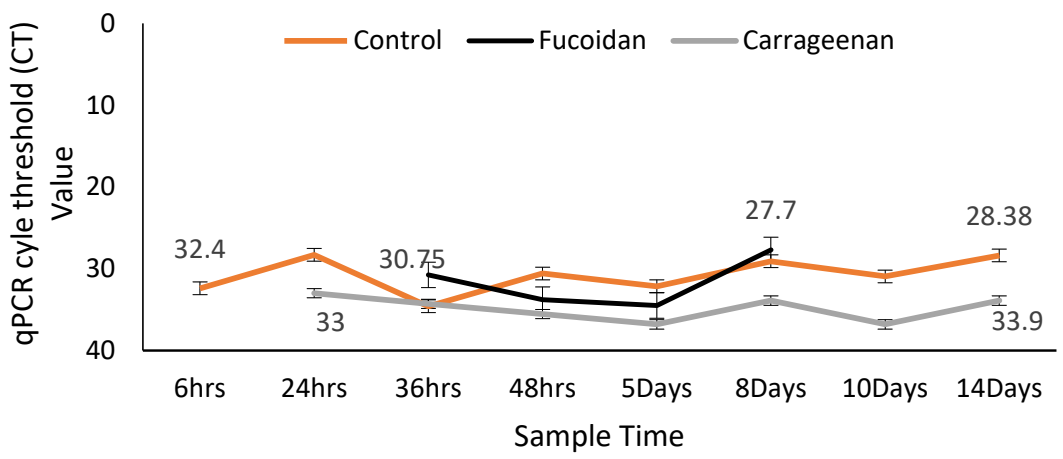

Figure 6. Quantitative PCR cycle threshold (CT) values shown at the start and end of the trial for each oyster group (fucoidan and carrageenan treated and untreated (control)). A CT value $>37$ is uninfected while the lower the CT value the higher the viral load being detected.

Overall, the carrageenan treated oysters had a significantly ( $p$ value 0.01 ) higher prevalence $(60.8 \%$ ) of Vibrio spp. (subsample sequenced as V. splendidus) by PCR, followed by the fucoidan treated oysters (21.8\%) and the control non-treated oysters (17.4\%) (Figure 7).

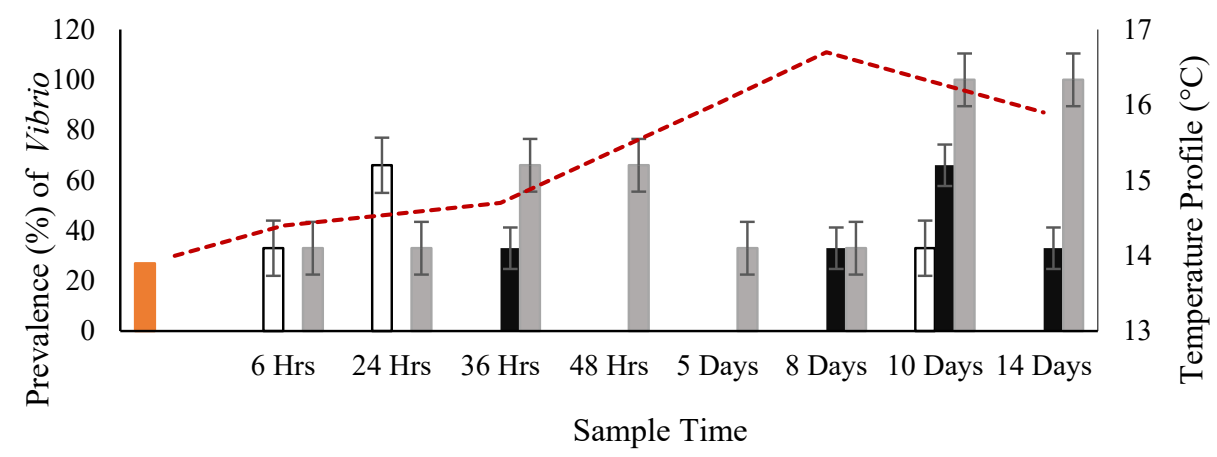

IS $\square$ Control $\square$ Carrageenan -----· Temperature

Figure 7. Vibrio splendidus prevalence (\%) by PCR in all oyster groups including ambient temperature. 
The carrageenan treated oysters had the highest overall prevalence of coinfections $(66.7 \%)$ of both pathogens followed by the control oysters $(22.2 \%)$ while the fucoidan treated oysters had the lowest prevalence of coinfections (11.1\%). Regardless of whether the oysters were treated or untreated the overall \% prevalence of coinfections with both oyster pathogens peaked at two specific time points during the trial study, from $24 \mathrm{~h}$ to $36 \mathrm{~h}$, and from Days 8 to 10. Each coinfection peak was preceded and was followed by a reduction in coinfections.

Both extracts had an immunostimulatory effect on the oysters, with a significant increase in total blood cell count (TBC) $(p<0.05)$ in carrageenan treated oysters (Figure 8), as well as an increase in granulocyte count (DBC) $(p<0.05)$ (Figure 9). Whilst the overall total blood cell count of the oysters in the control group did increase by $50.26 \%$ from start to finish, the oysters exposed to Carrageenan (60.35\%) and fucoidan $(80.24 \%)$ increased significantly more. The fucoidan measurements were found to just be outside the level of significance $(0.06>0.05)$, whilst the carrageenan measurements were statistically significant $(0.009<0.05)$. For all three oyster groups, there was no significant relationship between TBC and infection type. $\mathrm{P}$ values for carrageenan, fucoidan and control groups were all greater than 0.05 for OsHV-1 $\mu$ Var, Vibrio spp., and coinfection with both pathogens.

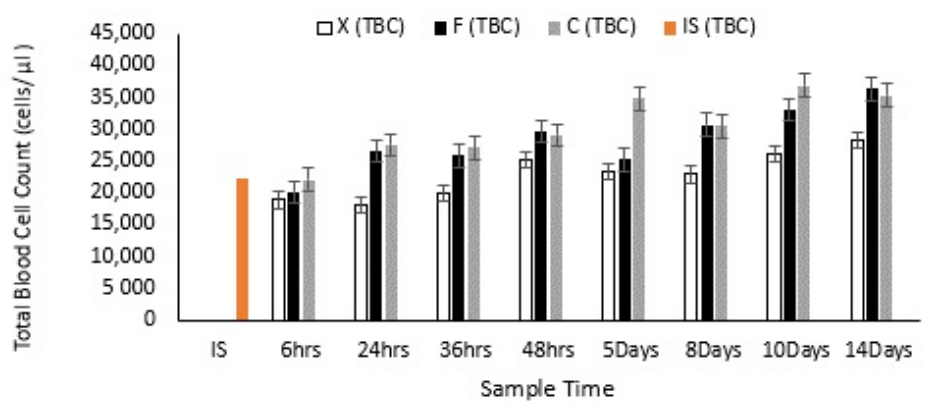

Figure 8. Total blood cell (TBC) count for the control and treated oysters, with the mean TBC for the Initial sample group (IS) also shown.

Granulocytes were at their highest in the control oysters at the start of the trial and showed a decrease throughout the trial period. Both algae extract treated oyster groups showed a statistically significant increase in granulocyte counts throughout the trial period (Figure 9). A statistical significance was found between DBC in oysters and algae extract treatment overall ( $p$ value $=0.0006$ ). Fucoidan had the highest level of significance on granulocyte production $(0.0001)$, followed closely by carrageenan $(0.0002)$.

(A)

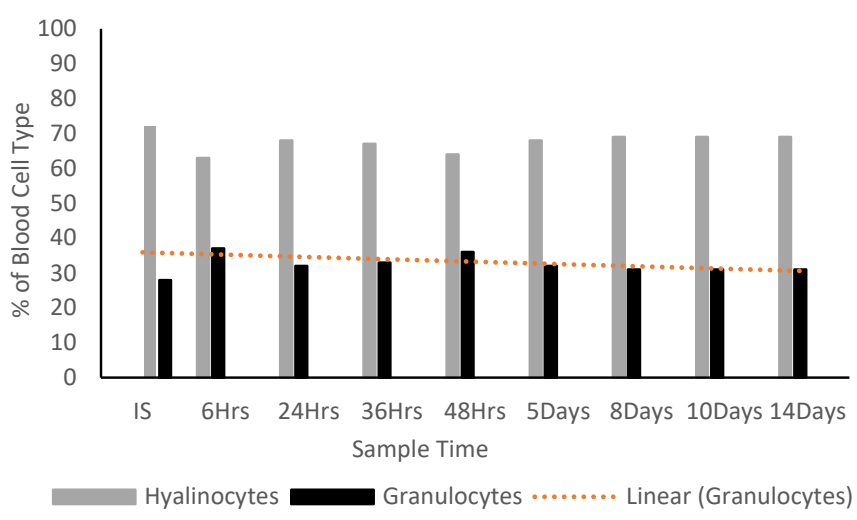

Figure 9. Cont. 
(B)
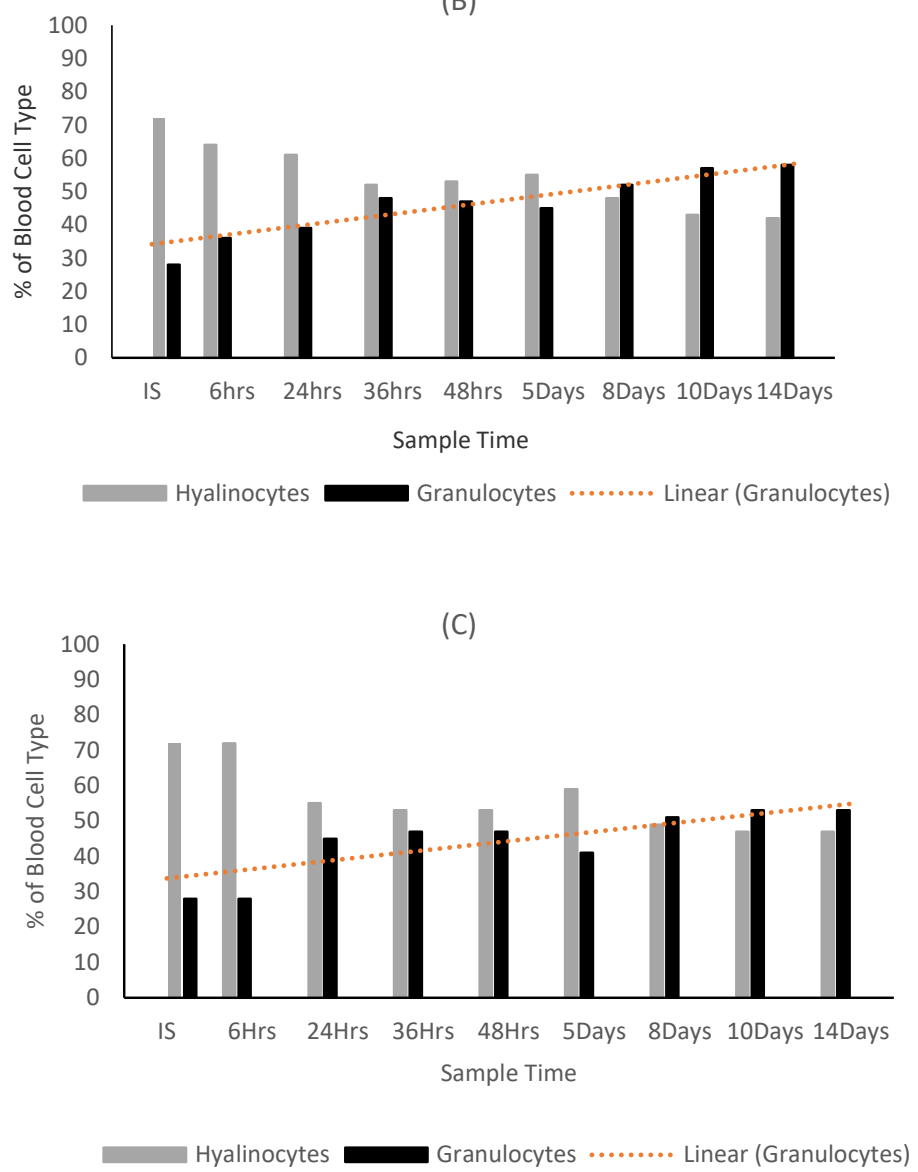

Figure 9. Ratio of hyalinocytes to granulocytes in the (A) control, (B) carrageenan treated and (C) fucoidan treated oysters.

\subsection{Effects of Sulphated Galactans on Palaemon Serratus}

No mortalities were observed in both P. serratus groups in the 10-Day trial.

Shrimp exposed to sulphated galactans showed an increase in THC compared to the control group quite early on (Days 3, 4 and 5) with a dose-dependent association being observed (Figure 10). Total haemocyte counts were significant higher in SG exposed groups compared to the control group quite early in the laboratory trial on Days 3, 4 and 5. Mean THC of control and of low and high concentration sulphated galactans treated groups on Day 3 were $9.127 \pm 1.71 \times 10^{5}, 10.672 \pm 3.98 \times 10^{5}$ and $13.512 \pm 4.32 \times 10^{5}$ cells $/ \mathrm{mL}$, respectively; on Day 4 were $6.367 \pm 5.69 \times 10^{5}, 17.326 \pm 2.73 \times 10^{5}$ and $13.886 \pm 4.75 \times 10^{5}$ cells $/ \mathrm{mL}$, respectively; and on Day 5 were $9.671 \pm 3.47 \times 10^{5}, 13.059 \pm 2.85 \times 10^{5}$ and $18.423 \pm 3.54 \times 10^{5}$ cells $/ \mathrm{mL}$, respectively.

An immunomodulatory effect, at a cellular level was observed in treated C. gigas and P. serratus, and when examined in C. gigas at a humoral level (elevated lysozyme amount). The enhanced physiological effects were observed at the earliest sampling time point for the C. gigas post exposure to intact seaweed spp. and derivatives ( $24 \mathrm{~h}$ and $6 \mathrm{~h}$, respectively). A slight increase in TBC over time was observed in the control oysters. This would have been due to a response of the oysters to the artificial holding conditions in the laboratory tanks and would be expected. However, what is important is that the increase in TBC is much greater in the dosed oysters compared to the control oysters thus highlighting a response to the fucoidan and carrageenan over time. 


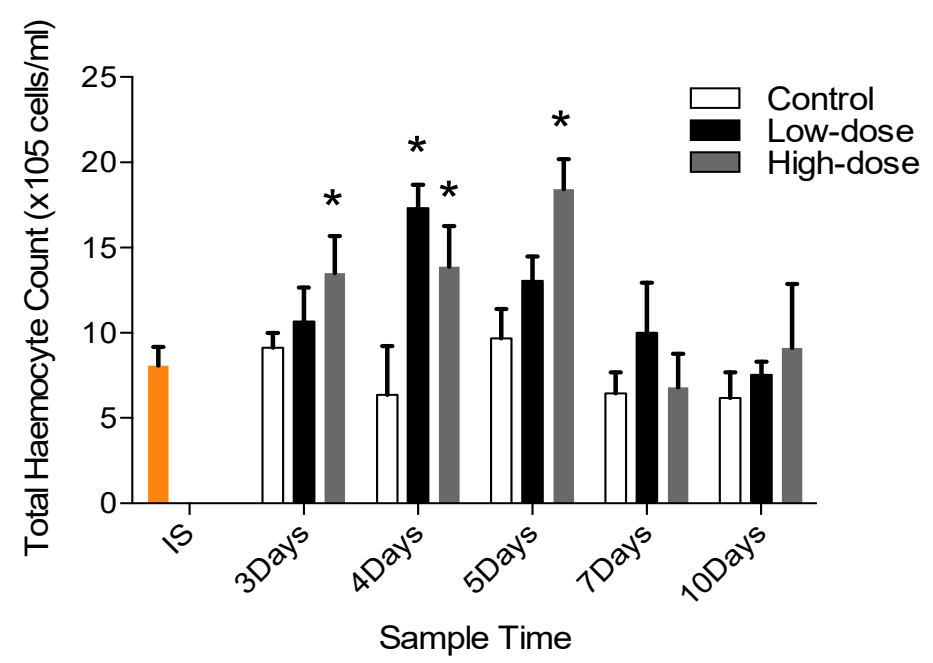

Figure 10. Total haemocyte count (THC) of the control and sulphated galactans treated P. serratus. The mean THC of the initial sample group (IS) is shown.* indicates statistical significant difference to the control.

In $P$. serratus exposed to sulphated galactans, the cellular effect was observed at the earliest sampling time point (Day 3). The control P. serratus had fluctuations in their THC possibly a response to the artificial holding conditions and lack of food. The experimental $P$. serratus were observed to be feeding on the sulphated galactans. Of significance, THC were significantly greater in P. serratus up to 5 days after the doses were administered. For both shellfish species the effects were prolonged lasting up to the end of each trial (26 days, 14 days and 10 days, respectively).

More importantly a reduction in OsHV-1 $\mu$ Var prevalence and viral replication was observed from Day 5 onwards in oysters exposed to the intact seaweeds, and from $24 \mathrm{~h}$ and $48 \mathrm{~h}$ for oysters exposed to $\mathrm{k}$-carrageenan and fucoidan. This delay in effect may have been due to the time taken for the natural leaching and accumulation of the seaweed bioactive compounds in the tanks. Of interest, OsHV-1 $\mu$ Var was not detected in C. gigas from Day 8 of the two-week trial, when oysters were exposed to fucoidan, even when a thermal environment $\left(\geq 16^{\circ} \mathrm{C}\right)$ conducive for viral activation and replication was present from $48 \mathrm{~h}$ after the trial began. Although the virus persisted in C. gigas exposed to $\kappa$ carrageenan, replication (viral load) was suppressed. This result is consistent with findings from previous studies studying the antiviral effects of red seaweed extracts, where WSSV viral expression and amplification in P. monodon was lower than in control individuals [40] (Wongprasert et al., 2014). The antiviral effect by sulphated polysaccharides and sulphated galactans is widely documented, acting to inhibit and interfere with the initial absorption of the virus by host cells [64]. No mortalities were observed in the control and experimental C. gigas, even though the virus was detected in both groups. The use of a selectively bred C. gigas stock, to be less susceptible to OsHV-1 $\mu$ Var, may explain this outcome or the acclimation/optimal holding conditions (water quality) of the trial did not induce a physiological stress response in the oysters, which would have made them more susceptible to infection.

Fucoidan and $\kappa$-carrageenan exposure did not have an antibacterial effect on $V$. splendidus and although this Vibrio sp. was present in the seaweed treated oysters, and at times double the prevalence of that of their control counterparts, it was not killing those oysters. V. splendidus, like most Vibrio strains, is an opportunistic pathogen that can cause significant mortalities in oysters in an optimum environment. It is recognized that environmental factors regulate the pathogenicity of $V$. splendidus and this bacteria group can enter a viable-but-nonculturable (VBNC) state when they are exposed to temperatures below $10^{\circ} \mathrm{C}$. Ambient temperatures during the trial were $>10{ }^{\circ} \mathrm{C}$, which would indicate viability of the $V$. splendidus present in the system. $V$. splendidus is a chemoorganotroph and is capable of metabolising alginate [65], 
which may explain the higher prevalence in the seaweed treated oysters. It may also be possible that non-pathogenic strains of $V$. splendidus were present in the system or it may be that vibriosis would require a longer time period before oysters succumb to infection. Whilst the algal extracts did not appear to have an antibacterial effect, they did have a positive impact on overall oyster health and their ability to fight bacterial infection and not to succumb to it. This is further supported by the significant coinfections of OsHV-1 $\mu$ Var and the V. splendidus in $\kappa$-carrageenan treated oysters, which did not result in mortality.

The present study demonstrated that SG stimulated haemocyte production in P. serratus. This increase in total blood cells was also observed in shrimp L. vannamei challenged with experimental Vibrio alginolyticus and fed fucoidan supplemented diets [66] and L. vannamei fed carrageenan [43]. Not only was there an increase in haemocyte counts in both of those studies but an increase in mitotic cells and the mitotic index in haematopoietic tissue was also observed. In another shrimp study, SG bound with an haemocyte membrane-like lipopolysaccharide binding protein and subsequently activated the downstream signaling pathway [64] which increased the proliferation of haemocytes and haematopoietic tissue mitotic index.

\section{Conclusions}

In conclusion, the findings of this study expand our knowledge on the health benefits of macroalgae in a globally important cultured mollusc species challenged by pathogens, and in an important commercially fished crustacean. Our results highlight the importance of macroalgae in nearshore coastal habitats and suggest a positive health effect of polyculture/treatment of $C$. gigas with brown and red seaweed species, that are commercial in their own right and are ubiquitous in near shore coastal environments. From an oyster culture perspective, the two-fold effect of boosting an oysters immune function while reducing OsHV-1 $\mu$ Var would be highly beneficial to the future sustainability of this global sector. Findings from this study further highlight the therapeutic potential of brown and red seaweeds on animal health and supports an increase in knowledge not only on additional invertebrate species that they impact but also their influence on a significant global pathogen group.

Author Contributions: Conceptualization, S.A.L., T.R., K.W., S.C.C.; methodology S.A.L., T.R., K.W., S.C.C.; validation S.A.L., T.R., K.W., S.C.C.; investigation R.B., B.B., T.R.; Writing-Original draft preparation, R.B., B.B., T.R.; Writing—Review and editing, S.A.L., T.R., K.W., S.C.C.; project administration, S.A.L.; funding acquisition S.A.L., T.R., K.W., S.C.C. All authors have read and agreed to the published version of the manuscript.

Funding: This research was funded for the Crassostrea gigas research by Reposus (FIRM DAFM Project reference number 14/F/820), Vivaldi (European Union's Horizon 2020 Grant Agreement No. 678589), Bluefish (Ireland Wales Interreg Programme Grant Agreement No. 80991) Projects and for the Palaemon serratus research by by the Thailand Research Fund (TRF) through the Royal Golden Jubilee Ph.D. Program to TR PHD/0148/2554.

Institutional Review Board Statement: Ethical review and and approval were waived for this study. The study species (Crassostrea gigas and Palaemon serratus) fall outside the Scientific Animal Protection S.1.543 legislation and Directive 2010/63/EU Directive on the Protection of Animals for Scientific Purposes and therefore do not require ethical approval for use in our research.

Data Availability Statement: Raw data was generated at University College Cork, Ireland. Derived data supporting the findings of this study are available from the corresponding author [SAL] on request.

Acknowledgments: The authors would like to thank Dungarvan Shellfish Ltd. (Harty Oysters) for providing the C. gigas and Rob Mc Allen for the sampling of the P. serratus.

Conflicts of Interest: The authors declare no conflict of interest. 


\section{References}

1. Løvstad Holdt, S.L.; Kraan, S. Bioactive compounds in seaweed: Functional food applications and legislation. J. Appl. Phycol. 2011, 23, 543-597. [CrossRef]

2. De Almeida, C.L.F.; Falcão, H.D.S.; Lima, G.R.D.M.; Montenegro, C.D.A.; Lira, N.S.; De Athayde-Filho, P.F.; Rodrigues, L.C.; Souza, M.D.F.V.D.; Barbosa-Filho, J.M.; Batista, L.M. Bioactivities from Marine Algae of the Genus Gracilaria. Int. J. Mol. Sci. 2011, 12, 4550-4573. [CrossRef]

3. Kesarcodi-Watson, A.; Miner, P.; Nicolas, J.-L.; Robert, R. Protective effect of four potential probiotics against pathogen-challenge of the larvae of three bivalves: Pacific oyster (Crassostrea gigas), flat oyster (Ostrea edulis) and scallop (Pecten maximus). Aquaculture 2012, 344-349, 29-34. [CrossRef]

4. Kawashima, T.; Murakami, K.; Nishimura, I.; Nakano, T.; Obata, A. A sulfated polysaccharide, fucoidan, enhances the immunomodulatory effects of lactic acid bacteria. Int. J. Mol. Med. 2011, 29, 447-453. [CrossRef] [PubMed]

5. Isnansetyo, A.; Fikriyah, A.; Kasanah, N. Murwantoko Non-specific immune potentiating activity of fucoidan from a tropical brown algae (Phaeophyceae), Sargassum cristaefolium in tilapia (Oreochromis niloticus). Aquac. Int. 2016, 24, 465-477. [CrossRef]

6. Craigie, J. Cell walls. In Biology of the Red Algae; Cole, K., Sheath, R., Eds.; Cambridge Univ. Press: Cambridge, UK, 1990; pp. 221-257.

7. McCandless, E.L.; Craigie, J.S. Sulfated Polysaccharides in Red and Brown Algae. Annu. Rev. Plant Physiol. 1979, 30, 41-53. [CrossRef]

8. $\quad$ Ehresmann, D.W.; Deig, E.F.; Hatch, M.T.; Disalvo, L.H.; Vedros, N.A. Antiviral substances from california marine algae1. J. Phycol. 1977, 13, 37-40. [CrossRef]

9. Richards, J.T.; Kern, E.R.; Glasgow, L.A.; Overall, J.C.; Deign, E.F.; Hatch, M.T. Antiviral Activity of Extracts from Marine Algae. Antimicrob. Agents Chemother. 1978, 14, 24-30. [CrossRef]

10. Laille, M.; Gerald, F.; Debitus, C. In vitro antiviral activity on dengue virus of marine natural products. Cell. Mol. Life Sci. 1998, 54, 167-170. [CrossRef]

11. Ghosh, P.; Adhikari, V.; Ghosal, P.K.; Pujol, C.A.; Carlucci, M.J.; Damonte, E.B.; Ray, B. In vitro anti-herpetic activity of sulfated polysaccharide fractions from Caulerpa racemosa. Phytochemistry 2004, 65, 3151-3157. [CrossRef]

12. Hidari, K.I.; Takahashi, N.; Arihara, M.; Nagaoka, M.; Morita, K.; Suzuki, T. Structure and anti-dengue virus activity of sulfated polysaccharide from a marine alga. Biochem. Biophys. Res. Commun. 2008, 376, 91-95. [CrossRef] [PubMed]

13. Catarino, M.D.; Silva, A.M.S.; Cardoso, S.M. Phycochemical consitutents and biological activities of Fucus spp. Mar. Drugs. 2018, 16, 249. [CrossRef]

14. Jönsson, M.; Allahgholi, L.; Sardari, R.R.R.; Hreggviðsson, G.O.; Karlsson, E.N. Extraction and modification of macroalgal polysaccharies fro current and next-generation applications. Molecules 2020, 25, 930. [CrossRef] [PubMed]

15. Pereira, L. Population Studies and Carrageenan Properties in Eight Gigartinales (Rhodophyta) from Western Coast of Portugal. Sci. World J. 2013, 2013, 1-11. [CrossRef] [PubMed]

16. Ale, M.T.; Mikkelsen, J.D.; Meyer, A.S. Important Determinants for Fucoidan Bioactivity: A Critical Review of Structure-Function Relations and Extraction Methods for Fucose-Containing Sulfated Polysaccharides from Brown Seaweeds. Mar. Drugs 2011, 9 , 2106-2130. [CrossRef] [PubMed]

17. Berg, J.A.; Newell, R.I. Temporal and spatial variations in the composition of seston available to the suspension feeder Crassostrea virginica. Estuar. Coast. Shelf Sci. 1986, 23, 375-386. [CrossRef]

18. Lynch, S.A.; Dillane, E.; Carlsson, J.; Culloty, S.C. Development and assessment of a sensitive and cost-effective polymerase chain reaction to detect ostreid herpesvirus 1 and variants. J. Shellfish. Res. 2013, 32, 1-8. [CrossRef]

19. Schmitt, P.; Duperthuy, M.; Montagnani, C.; Bachère, E.; Destoumieux-Garzón, D. Immune Responses in the Pacific Oyster Crassostrea gigas an Overview with Focus on Summer Mortalities in Oyster's Physiology, Ecological Distribution and Mortality; Qin, J., Ed.; Nova Science Publishers, Inc.: New York, NY, USA, 2012.

20. Kakehi, S.; Kamiyama, T.; Abe, H.; Hanawa, S.; Oota, H.; Matsuura, R.; Oshino, A. Mechanisms leading to the decline in Pacific oyster Crassostrea gigas seedlings in Matsushima Bay, Japan. Fish. Sci. 2016, 82, 499-508. [CrossRef]

21. Whittington, R.J.; Paul-Pont, I.; Evans, O.; Hick, P.; Dhand, N.K. Counting the dead to determine the source and transmission of the marine herpesvirus OsHV-1 in Crassostrea gigas. Veter-Res. 2018, 49, 1-21. [CrossRef] [PubMed]

22. Ryan, H.J.; Williams, K.F.; Kaiser, M.J. A Review of the Palaemon Serratus Fishery: Biology, Ecology and Management, Fisheries and Conservation Report 2014 No. 38; Bangor University: Wales, UK, 2014.

23. Galloway, T.S.; Depledge, M.H. Immunotoxicity in invertebrates: Measurement and ecotoxicological relevance. Ecotoxicology 2001, 10, 5-23. [CrossRef]

24. Mydlarz, L.D.; Jones, L.E.; Harvell, C.D. Innate Immunity, Environmental Drivers, and Disease Ecology of Marine and Freshwater Invertebrates. Annu. Rev. Ecol. Evol. Syst. 2006, 37, 251-288. [CrossRef]

25. Allam, B.; Raftos, D. Immune responses to infectious diseases in bivalves. J. Invertebr. Pathol. 2015, 131, 121-136. [CrossRef]

26. Medzhitov, R.; Janeway, C.A. Innate immunity: Impact on the adaptive immune response. Curr. Opin. Immunol. 1997, 9, 4-9. [CrossRef]

27. Li, C.; Weng, S.; He, J. WSSV-host interaction: Host response and immune evasion. Fish Shellfish. Immunol. 2019, 84, 558-571. [CrossRef] [PubMed] 
28. Bachere, E.; Gueguen, Y.; Gonzalez, M.; De Lorgeril, J.; Garnier, J.; Romestand, B. Insights into the anti-microbial defense of marine invertebrates: The penaeid shrimps and the oyster Crassostrea gigas. Immunol. Rev. 2004, 198, 149-168. [CrossRef]

29. Gestal, C.; Roch, P.; Renault, T.; Pallavicini, A.; Paillard, C.; Novoa, B.; Oubella, R.; Venier, P.; Figueras, A. Study of diseases and the immune system of bivalves using molecular biology and genomics. Rev. Fish. Sci. Aquac. 2008, 16, 131-154. [CrossRef]

30. Gagnaire, B.; Frouin, H.; Moreau, K.; Thomas-Guyon, H.; Renault, T. Effects of temperature and salinity on haemocyte activities of the Pacific oyster, Crassostrea gigas (Thunberg). Fish Shellfish. Immunol. 2006, 20, 536-547. [CrossRef]

31. Chu, F.-L.E.; La Peyre, J.F. Effect of environmental factors and parasitism on hemolymph lysozyme and protein of American oysters (Crassostrea virginica). J. Invertebr. Pathol. 1989, 54, 224-232. [CrossRef]

32. Cronin, M.; Culloty, S.; Mulcahy, M. Lysozyme activity and protein concentration in the haemolymph of the flat oyster Ostrea edulis (L.). Fish Shellfish. Immunol. 2001, 11, 611-622. [CrossRef] [PubMed]

33. Prado-Alvarez, M.; Darmody, G.; Hutton, S.; O’Reilly, A.; Lynch, S.A.; Culloty, S.C. Occurrence of OsHV-1 in Crassostrea gigas Cultured in Ireland during an Exceptionally Warm Summer. Selection of Less Susceptible Oysters. Front. Physiol. $2016,7,492$. [CrossRef] [PubMed]

34. Scholz, U.; Diaz, G.G.; Ricque, D.; Suarez, L.C.; Albores, F.V.; Latchford, J. Enhancement of vibriosis resistance in juvenile Penaeus vannamei by supplementation of diets with different yeast products. Aquaculture 1999, 176, 271-283. [CrossRef]

35. Ganz, T. The Role of Antimicrobial Peptides in Innate Immunity. Integr. Comp. Biol. 2003, 43, 300-304. [CrossRef] [PubMed]

36. Yang, C.; Hao, R.; Deng, Y.; Liao, Y.; Wang, Q.; Sun, R.; Jiao, Y.; Du, X. Effects of protein sources on growth, immunity and antioxidant capacity of juvenile pearl oyster Pinctada fucata martensii. Fish Shellfish. Immunol. 2017, 67, 411-418. [CrossRef] [PubMed]

37. Carboni, S.; Clegg, S.H.; Hughes, A.D. The use of biorefinery by-products and natural detritus as feed sources for oysters (Crassostrea gigas) juveniles. Aquaculture 2016, 464, 392-398. [CrossRef]

38. Tanyaros, S.; Chuseingjaw, S. A partial substitution of microalgae with single cell detritus produced from seaweed (Porphyra haitanensis) for the nursery culture of tropical oyster (Crassostrea belcheri). Aquac. Res. 2014, 47, 2080-2088. [CrossRef]

39. Rudtanatip, T.; Lynch, S.A.; Wongprasert, K.; Culloty, S.C. Assessment of the effects of sulfated polysaccharides extracted from the red seaweed Irish moss Chondrus crispus on the immune-stimulant activity in mussels Mytilus spp. Fish Shellfish. Immunol. 2018, 75, 284-290. [CrossRef]

40. Wongprasert, K.; Rudtanatip, T.; Praiboon, J. Immunostimulatory activity of sulfated galactans isolated from the red seaweed Gracilaria fisheri and development of resistance against white spot syndrome virus (WSSV) in shrimp. Fish Shellfish. Immunol. 2014, 36, 52-60. [CrossRef]

41. Sinurat, E.; Saepudin, E.; Peranginangin, R.; Hudiyono, S. Immunostimulatory activity of brown seaweed-derived fucoidans at different molecular weights and purity levels towards white spot syndrome virus (WSSV) in shrimp Litopenaeus vannamei. J. Appl. Pharm. Sci. 2016, 6, 082-091. [CrossRef]

42. Cantelli, L.; Goncalves, P.; Guertler, C.; Kayser, M.; Pilotto, M.R.; Barracco, M.A.; Perazzolo, L.M. Dietary supplementation with sulfated polysaccharides from Gracilaria birdiae promotes a delayed immunostimulation in marine shrimp challenged by the white spot syndrome virus. Aquac. Int. 2018, 27, 349-367. [CrossRef]

43. Chen, Y.-Y.; Sim, S.S.; Chiew, S.L.; Yeh, S.-T.; Liou, C.-H.; Chen, J.-C. Dietary administration of a Gracilaria tenuistipitata extract produces protective immunity of white shrimp Litopenaeus vannamei in response to ammonia stress. Aquaculture 2012, 370-371, 26-31. [CrossRef]

44. Cunha, L.; Grenha, A. Sulfated Seaweed Polysaccharides as Multifunctional Materials in Drug Delivery Applications. Mar. Drugs 2016, 14, 42. [CrossRef]

45. Manilal, A.; Selvin, J.; Sugathan, S. Immuno-Modulatory Efficacy of Indian Red Algae, Asparagopsis taxiformis, in Penaeus monodon. J. Appl. Aquac. 2013, 25, 81-93. [CrossRef]

46. Jasmanindar, Y.; Sukenda, S.; Zairin, M., Jr.; Alimuddin, A.; Utomo, N.B. Dietary administration of Gracilaria verrucosa extract on Litopenaeus vannamei immune response, growth, and resistance to Vibrio harveyi. Aquacult. Aquar. Conserv. Legis. 2018, 11, 1069-1080.

47. Manilal, A.; Selvin, J.; George, S. In vivo therapeutic potentiality of red seaweed, Asparagopsis (Bonnemaisoniales, Rhodophyta) in the treatment of Vibriosis in Penaeus monodon Fabricius. Saudi J. Biol. Sci. 2012, 19, 165-175. [CrossRef] [PubMed]

48. Steentoft, M.; Farnharn, W.F. Northern distribution boundaries and thermal requirements of Gracilaria and Gracilariopsis (Gracilariales, Rhodophyta) in Atlantic Europe and Scandinavia. Nord. J. Bot. 1997, 17, 87-94. [CrossRef]

49. Hardy, F.G.; Guiry, M.D. A Check-List and Atlas of the Seaweeds of Britain and Ireland; British Phycological Society: London, UK, 2003; ISBN 0-9527115-1-6.

50. Ruperez, P. Mineral content of edible marine seaweeds. Food Chem. 2002, 79, 23-26. [CrossRef]

51. Gómez-Ordóñez, E.; Jiménez-Escrig, A.; Rupérez, P. Bioactivity of sulfated polysaccharides from the edible red seaweed Mastocarpus stellatus. Bioact. Carbohydr. Diet. Fibre 2014, 3, 29-40. [CrossRef]

52. Walsh, P.S.; Metzger, D.A.; Higuchi, R. Chelex 100 as a Medium for Simple Extraction of DNA for PCR-Based Typing from Forensic Material. Biotechniques 2013, 54, 134-139. [CrossRef] [PubMed]

53. Webb, S.C.; Fidler, A.; Renault, T. Primers for PCR-based detection of ostreid herpes virus-1 (OsHV-1): Application in a survey of New Zealand molluscs. Aquaculture 2007, 272, 126-139. [CrossRef] 
54. Carballal, M.J.; Lopez, C.; Azevedo, C.; Vilalba, A. Enzymes involved in defence function of hemocytes of mussel Mytilus galloprovincialis. J. Invertebr. Pathol. 1997, 70, 96-105. [CrossRef]

55. McCleary, S.; Henshilwood, K. Novel quantitative TaqMan ${ }^{\circledR}$ MGB real-time PCR for sensitive detection of Vibrio aestuarianus in Crassostrea gigas. Dis. Aquat. Org. 2015, 114, 239-248. [CrossRef]

56. Kett, G.F.; Culloty, S.C.; Jansen, M.A.K.; Lynch, S.A. Development of a Sensitive Polymerase Chain Reaction (PCR) and DIG-Labelled in situ Hybridisation (ISH) for the Detection of Vibrio Bacteria; University College Cork: Cork, Ireland, 2021; Unpublished.

57. Notaro, D.A.; Culloty, S.C.; Lynch, S.A. A pilot study investigating the potential of antimicrobial photodynamic therapy (aPDT) to control Vibrio spp. development in microalgae and seawater. Aquac. Int. 2021, 29, 355-372. [CrossRef]

58. Walberg, J. White blood cell counting techniques in birds. Semin. Avian Exot. Pet Med. 2001, 10, 72-76. [CrossRef]

59. Carisch, L.; Stirn, M.; Hatt, J.M.; Federer, K.; Hofmann-Lehmann, R.; Riond, B. White blood cell count in birds: Evaluation of a commercially available method. BMC Veter-Res. 2019, 15, 1-7. [CrossRef] [PubMed]

60. Liu, Z.; Wang, L.; Zhou, Z.; Sun, Y.; Wang, M.; Wang, H.; Hou, Z.; Gao, D.; Gao, Q.; Song, L. The simple neuroendocrine-immune regulatory network in oyster Crassostrea gigas mediates complex functions. Sci. Rep. 2016, 6, 26396. [CrossRef] [PubMed]

61. Gerdol, M.; Gomez-Chiarri, M.; Castillo, M.G.; Figueras, A.; Fiorito, G.; Moreira, R.; Novoa, B.; Pallavicini, A.; Ponte, G.; Roumbedakis, K.; et al. Immunity in Molluscs: Recognition and Effector Mechanisms, with a Focus on Bivalvia. In Advances in Comparative Immunology; Metzler, J.B., Ed.; Springer: New York City, NY, USA, 2018; pp. 225-341.

62. Usov, A.I. Polyscaccharides of the red algae. Adv. Carb. Chem. Biochem. 2011, 65, 115-217.

63. Sritunyalucksana, K.; Gangnonngiw, W.; Archakunakorn, S.; Fegan, D.; Flegel, T.W. Bacterial clearance rate and a new differential hemocyte staining method to assess immunostimulant activity in shrimp. Dis. Aquat. Org. 2005, 63, 89-94. [CrossRef]

64. Rudtanatip, T.; Withyachumnarnkul, B.; Wongprasert, K. Sulfated galactans from Gracilaria fisheri bind to shrimp haemocyte membrane proteins and stimulate the expression of immune genes. Fish Shellfish. Immunol. 2015, 47, 231-238. [CrossRef] [PubMed]

65. Wargacki, A.J.; Leonard, E.; Win, M.N.; Regitsky, D.D.; Santos, C.N.S.; Kim, P.B.; Cooper, S.R.; Raisner, R.M.; Herman, A.; Sivitz, A.B.; et al. An Engineered Microbial Platform for Direct Biofuel Production from Brown Macroalgae. Science 2012, 335, 308-313. [CrossRef] [PubMed]

66. Kitikiew, S.; Chen, J.-C.; Putra, D.F.; Lin, Y.-C.; Yeh, S.-T.; Liou, C.-H. Fucoidan effectively provokes the innate immunity of white shrimp Litopenaeus vannamei and its resistance against experimental Vibrio alginolyticus infection. Fish Shellfish. Immunol. 2013, 34, 280-290. [CrossRef] 